\title{
A HATÁRMENTI EGYÜTTMÜKÖDÉS NEMZETKÖZI RENDSZEREI: NÉMETORSZÁG, LENGYELORSZÁG ÉS AZ EU
}

\author{
(Transboundary Regionalism within International Regimes: Germany, \\ Poland and the EU)
}

\section{JAMES SCOTT $^{1}$}

Az Európai Unión belưl a határokon átnyúló térségi egyuittmüködést segitő szervezetek fejlődése gyorsan halad elöre, ami az integrációs folyamatnak és az EUpolitikák megvalósításának fontos eleme. Az Eurorégiók széles körben ismert modelljét alkalmazták a német-lengyel határmenti térségben - amelyet a gyors politikai és gazdasági átalakulások jellemeznek - az EU bővítésének megkönnyitése, valamint Közép-Európa, az új német tartományok és az Európai Unió többi része közötti térbeli kohézió erősítése eszközeként.

A határmenti együttműködés különböző indítékok, lehetöségek és stratégiai megfontolások eredöjeként alakul ki. Közigazgatási és intézményi struktúrák, nemzetközi összefüggések, a nemzetállamok politikai szempontjai, a kulturális, nyelv és a történelmi fejlődés sajátosságai formálják az együttmükődés kereteit. Ezen tényezők egyaránt befolyásolják a belső kohéziót (a tényleges együttmũködést) és a határmenti térségeknek, mint (Soldatos kifejezésével élve) "szub-nemzeti paradiplomácia" megvalósítóinak megjelenését, szerepét. Ezért minden határmenti térségre jellemző a határon átnyúló kapcsolatok és összefüggések sajátos konstellációja, amely a nemzetközi térségi együttmükődés fejlődését meghatározza. Jelen tanulmány egyszerüsített analitikus kereteket alkalmaz a német-lengyel határmenti térségre. A rendszerelmélet koncepcióját felhasználva - amely a határon átnyúló kezdeményezések szabályait, normáit, stratégiai szempontjait és eszközeit foglalja magában - tárgyaljuk az EU határmenti térségi politikájának és a német-lengyel együttmüködés sajátos környezetének kölcsönhatását.

Amint azt e tanulmány is érzékelteti, az együttmüködés konkrét eredményei vegyesek. Az intézmények kiépítése sikeres volt, a térségi fejlesztési politika célkitüzései és a helyi stratégiai tervezés fejlesztésének eredményei azonban nehezen értelmezhetöek. A szerző kísérletet tesz annak bemutatására, hogy a német-lengyel határon átnyúló egyưttmükődés intézményei formái miként hatottak müködési környezetükre az elmúlt hat év során, és eközben mennyiben sikerült a térségi problémákat új megvilágításba helyezniük, ami a figyelmet a határokon átnyúló együttmüködés fontosságára irányította. Az azonban továbbra is nyitott kérdés marad, hogy ezen fejlemények a bővülő EU-n belüli német-lengyel határmenti térségek jelentősebb politikai és gazdasági szerepét jelzik-e. 


\section{A határmenti kapcsolatok, együttmüködések globális összefüggései}

A határmenti regionális együttmüködés jelensége az államok közötti verseny, érintkezés, alku, és együttmüködés komplex folyamatának részét képezi (Cappelin 1993, Ratti 1988). A határmenti térségek a tartományokhoz, városokhoz és más, szub-nemzeti szereplökhöz hasonlóan paradiplomáciai eszközökkel élnek érdekeik érvényesítéséért (Scott 1989, Clement 1996). A térségek belső kohéziója, illetve a külső politikai és gazdasági nyomásra adott "reakcióik" egyaránt megmérettetnek (Duchacek 1986). Az államközi integráció - mint amilyen az Európai Unióban vagy az Észak-Amerikai Szabadkereskedelmi Társulás országaiban zajlik - által erösített kölcsönös függés (elsösorban globális, ökológiai értelemben) és a nemzetállam politikaformáló képességeire nehezedö egyre több kihívás, úgy tünik, javitotta a térségi és helyi, határokon átnyúló együttmüködési kezdeményezések feltételeit.

Feltételezték, hogy a határokon átnyúló térségi fejlesztési stratégiák nem csak a helyi, hanem végső soron nemzetgazdasági érdekeket is szolgálnak (Koch 1974). Különösen igaz ez Európában, ahol az integrációs imperatívusz „nyilvánvalóvá vált azáltal, hogy a (nyitott) európai piaci tér létrehozás gazdasági és politikai szükségszerüséggé vált" (Ratti 1993). Az az érv is felmerült, hogy az ökológiai szükségszerüség által vezérelt, a területi tervezési, gazdasági és kulturális téren müködő helyi szintü együttmüködés az informális szférából szélesebb körü nemzetközi koordináció szinterévé, majd alkalmasint politikai integrációvá fejlödhet (Becker-Mark 1992). Ezek az érvek "racionális" alapot teremtenek az együttműködés elömozdítását és megkönnyitését segítö politikák kidolgozásához a határmenti területeken. Ez tükröződik az EU strukturális és tervezési politikájában is, amelynek célja a térségi kezdeményezések erősitése, illetve a régiók nemzetközi szövetségei létrehozásának támogatása. ${ }^{2} \mathrm{Az}$ európai határmenti térségek régóta részesei a paradiplomáciai tevékenységeknek, mellyel a nemzeti politikák hiányosságaira és a helyi/regionális döntéshozatali autonómia folyamatos korlátozására reagáltak. ${ }^{3}$ Ennek eredményeként, bár sok esetben más okok miatt is, a szub-nemzeti diplomáciát támogatták a határmenti egyưttmüködés aktivistái, számos nemzeti kormány és az európai politikaformáló tisztviselök.

A szub-nemzeti paradiplomáciai tevékenység elterjedése igazolja a konvergenciaelméletek azon híveit, akik bizonyos folyamatosságot látnak a probléma-megoldó intézmények fejlödésében, ahol a globális nyomás által felerősített intézményi verseny (Boyer 1996) az intézményi tervezést és gyakorlatot az új gazdasági és politikai kérdésekhez igazitja. Ezen feltevésnek a határmenti térségekre történő alkalmazásával feltételezhetjük, hogy a gazdaság globalizációja - különösen az EU és a NAFTA fölrésznyi integrációs keretein belül - a kölcsönös függőség erösödéséhez és a határoknak, mint a kirekesztés eszközeinek eltünéséhez vezet. A "konvergencia"-érvet részben alátámasztja, hogy a helyi és nemzeti kormányzatok önkéntes részvételén alapuló határon átnyúló együttmüködési szervezeteket, Eurorégiókat hoznak létre az Európai Unió külső határai mentén és számos Középés Kelet-Európai ország között.

A kölcsönös függőség logikája és az új problémamegoldó mechanizmusok kialakításának szükségessége gyakran ütközik a nemzeti érdekekkel, és ellentmondásba kerül a határmenti együttmüködés szereplöi által megteremtett 
intézményi határokkal (Duchacek 1987). A határon átnyúló együttmũködés síkere így annak a kölcsönhatásnak a fúggvénye, amely a politikai, társadalmi és gazdasági környezettel áll fönn, amelyben a kapcsolat müködik. Ez a határmenti térségek belsō kohézióját és felruházza azokat egyfajta sajátos identitással. Következésképpen a nem adminisztratív jellegü, hanem a tényleges együttmüködésekre épülö szerzödések által meghatározott nemzetkőzi határmenti térségek csak akkor életképesek és a felmerülő problémáikat akkor tudják megoldani, ha nemzeti és nemzetek fölötti szervezetektöl, intézményektöl támogatást kapnak.

A határmenti együttmüködés szervezeteinek gyors fejlödése e térségeknek politikai tartalmat és szerepet biztositott, továbbá új európai területi dimenziók kialakitását eredményezte. A konfliktus-kezelés új - bár korlátozott döntéshozatali hatalommal felruházott - színterei alakulnak ki a nemzetállamok és térségek európai mozaikján belül. Ugyanakkor a folyamat nem olyan töretlen, mint amilyennek látszik. Az Európai Unióban két intézményesitési stratégiával szándékoziknak elérni két, némiképp ellentmondó célkitüzést: az egyik a szub-nemzeti (határmenti) paradiplomácia felügyelete, a másik az informális, helyi szintũ, határon átnyúló kapcsolatrendszer újszerŭ és hatékony rendszereinek támogatása, amely az integráció ösztönzöje lehet (Church; Reid 1995). A lényegre Gress (1966), Scheiber (1993) és mások mutattak rá, miszerint a nemzetek feletti kormányzási struktúra létrehozása (például az EU esetében) esetenként korlátozhatja is a politikai folyamatokat a szub-nemzeti szinteken, ugyanakkor a szabadkereskedelem és a növekvő verseny nagyobb kezdeményezökészséget igényel az egyes régióktól. Az európai és a nemzeti politikák egyre szövevényesebbé váló rendszere sok esetben erodálta a helyi, regionális kormányzatok hatáskörét, még a fejlett szövetségi rendszerekben is, mint például a Németország (Scharpf 1985).

A jelen tanulmány célja az, hogy a német-lengyel határon átnyúló térségi folyamatok és az európai integrációs folyamatok közötti összefüggéseket vizsgálja, amelyeknek kereteit az EU határmenti együttmüködéseket támogató, nemzetek fölötti politikája biztositsa. Ganster és Sweedler (1990), Cappelin (1993), Ratti (1988, 1993), Scott et al. (1996) szerint a folyamat meghatározói egymással összefưggő tényezők rendszere és a helyi intézmények. Ezek közül legfontosabbak: a nemzeti szuverenitás kőzös értelmezése, (pl. szabadkereskedelmi szerződések és úgynevezett biztonságpolitikai szővetségek formájában), a kölcsönös gazdasági fúggő́ség foka, a nemzeti érdekek konvergenciája, a határon átnyúló mozgás viszonylagos szabadsága, ide értve a munkaerỏ áramlását is, a kölcsönös kulturális megértés és nyelvikapcsolatok, a gazdasági és politikai hatalom nemzeti központjaihoz viszonyított perifériális jelleg a tárgyalt térségekben, a társadalmigazdasági, szervezeti rendszerek hasonlósága, és olyan negatív külsö tényezök fenyegetése, amelyek egyoldalú intézkedésekkel nem kezelhetök. Jóllehet minden ilyen tényezö fontos, azonban ezeket analizissel rendszerezni kell annak érdekében, hogy tisztább képet kapjunk az egyes határmenti térségek helyzetéröl.

Duchacek definiciója szerint a "a kormányzati rendszer formális és informális szabályok és intézmények halmaza, amelynek célja és tevékenysége a közvetlen környezet (térség) viselkedésének szabályozása" (1986). Tanulmányunkban azt vizsgáljuk, hogy a nemzeti határokon átivelö szervezeti-intézményi keretek - mint például az európai határmenti térségekkel kapcsolatos politika - miként hatottak, 
milyen kapcsolatban voltak a német-lengyel határmenti térség helyi együttmüködési környezetével. A határon átnyúló együttmüködés meghatározói kerülnek tárgyalásra a két nemzetet felölelō térbeli tervezési intézményeknek a két nemzetre kiterjedő térségben történō fejlōdésével kapcsolatban. Ezen megfigyelések alapján a németlengyel határon átnyúló térségi tevékenység jövöbeni szerepének lehetséges változatait vázoljuk fel, tekintettel az EU-integrációra és a kelet felé való terjeszkedésre.

\section{Együttmüködési rendszerek a német-lengyel határmenti térségben}

A kezdeti habozás és fenntartások ellenére az EU Bizottsága aktív támogatást nyújtott a helyi és regionális, határokon átnyúló együttműködés fejlesztéséhez az elmúlt tíz év során. Ez a támogatás az EU-politika decentralizálásával, illetve regionalizálásával (Madiot 1996) kapcsolatos vita, a térségek közötti versenyt és a helyi vállalkozói kezdeményezést hangsúlyozó térségi fejlesztési programok reformjai (Syrett 1993) és az általános európai gazdasági kohézió szempontjai (Williams 1996) eredménye. A tagországok ezen kivül felismerték, hogy az EU-n belüli határmenti térségeket jellemző politikai és gazdasági kapcsolatok alacsony szintje erősíti a polarizációt és negativan hat az európai versenyképességre is ( $E U$ Bizottság 1993; Millan 1994). ${ }^{4}$

Az Európa Tanács, a regionális és helyi hatóságok és az Európai Határmenti Térségek Szövetsége ösztönzésére az EU számos kezdeményezést indított el azzal a céllal, hogy ösztönözze a határon átnyúló együttmüködést információcserék és a helyi, illetve térségi szinten megvalósított együttmükődési programok pénzügyi támogatása révén. Az Európai Szociális Alap (ESF), az Európai Regionális Fejlesztési Alap (ERDF) és az Európai Mezōgazdasági Alap (EAGGF) által finanszírozott INTERREG nevü közösségi kezdeményezés 1990 óta több mint 2 milliárd ECU-t költött a határmenti térségek integrált fejlesztéseire. ${ }^{5}$

Az INTERREG és az ehhez csatlakozó programok részét képezik egy nemzetközi megállapodásokon alapuló határmenti regionális politikának, amely a nemzetállamoknak fontos közvetítő és felügyeleti szerepet szán. Az utóbbi a regionális szint autonómiájának függvényében az egyes tevékenységi területeken eltérö mértékü lehet. Az EU-n belüli, és a nemzeti, térségi és helyi hatóságok közötti együttmüködés átalakítja a nemzetállamok és térségek közötti kapcsolatokat. A jelenlegi strukturális és kohéziós politika csökkentette a nemzetállamok "kapuöri" funkcióit, melynek következtében a helyi és regionális kormányzatok kapcsolatai közvetlenebbé válnak Brüsszellel és ugyanilyen módon az EU közvetlenebbül avatkozik be a régiók ügyeibe (Hooghe és Marks 1996). ${ }^{6}$ Ugyanakkor az EU strukturális politikája mind nagyobb nyomást fejt ki a térségekre annak érdekében, hogy az agressziv promóciós stratégia megvalósitására ösztönőzve azokat.

A nemzeti szuverenitás felfüggesztését valamennyi tagállam elfogadta, a gazdasági integráció kínálta gazdasági előnyeinek kihasználása érdekében. Ehhez a tőke és a munkaerō nagyobb mobilitása és rugalmasabb politikaformáló mechanizmusok szükségesek. Az Egységes Európai Piac, a közösségi politikák kereteinek megteremtésével és az Európai Bíróság és a Nyugat-Európai (védelmi) Unió (WEU) fejlesztésével haladt elöre leginkább az államkőzi integráció és a 
nemzetek fölötti szervezetek létrehozása révén. Körvonalazódik egy markáns határmenti regionális politika képe az EU-n belül, amely már nem csupán a támogatások odaítélésének irányelveit körvonalazza, hanem határozott normatív elemeket is tartalmaz. Jelen tanulmány egy olyan, határokon átnyúló együttmüködési rendszerrel foglalkozunk, amelynek saját belső logikája van, és melynek célja a határmenti régiók fejlödésének elösegítése és a kooperáció szabályozása. (1. táblázat). Az EU-nak jelentös szerepe van ebben a folyamatban, mivel a strukturális politika keretei között támogatja az együttmüködési kezdeményezéseket. A rendszernek fontos eleme az alulról felfelé történő építkezés, vagyis a határmenti térségek képviselhetik saját szempontjaikat és érdekeiket az Európa Tanács, az AEBR (Európai Határmenti Térségek Szövetsége), az Európa Parlament és más nemzetközi testületek által szervezett konferenciákon. ${ }^{7}$

Az európai határokon átnyúló együttmüködési rendszerek létrehozását sok tényezö ösztönzi, többek között az új piacok megnyitása, az európai biztonsági érdekek és az általános politikai stabilitás fenntartása, a gazdasági kohézió és életképesség, a tágabb értelemben vett európai együttmüködés és integráció negatív társadalmi hatásainak kiküszöbölése, és az átmenet korszakát élö nemzeti és regionális gazdasági bázisok dinamizálása. ${ }^{8} \mathrm{Az}$ intézmények kiépítését számos kormányközi testület, valamint helyi és regionális együttmüködések ösztönzik, a határokon átnyúló együttmüködési tevékenység koordinálása céljából. Különösen ösztönzik az önkormányzatok határokon átnyúló szövetségeinek létrehozását. Ez a regionális igazgatás újabb szintjét jelentik és fontos szerepet játszanak az INTERREG pénzeszközeinek közvetítésében a határmenti térsége felé. Feladatuk a határokon átnyúló, térségi fejlesztési programok kidolgozása, amelyek a pénzeszközök felhasználásának cselekvési terveket adnak az érintett kormányok és az EU általi jóváhagyást követően. ${ }^{9}$

A Közép- és Kelet-Európai országok (CEEC) az 1989-1990-es változások óta szoros gazdasági és politikai kapcsolatok kiépitésére törekszenek az Európai Unióval és más európai integrációs intézményekkel. Stratégiai okok miatt ezen kezdeményezéseket komolyan támogatták, hiszen a korábbi "keleti tömb" országainak gazdasági és politikai stabilitása, illetve gazdasági dinamizmusa nem csak az európai biztonság, hanem az EU prosperitása szempontjából is lényeges. Lengyelország és a többi Közép-Európai ország esetében a határokon átnyúló együttmüködési rendszer az EU általános, "pre-integrációs" politikáját tükrözi, melynek célja a társult államok alkalmazásának elősegitése az európai törvénykezési és szabályozási környezethez. ${ }^{10}$

Az egyes EU-tagállamok gyakran hangoztatják az EU-n kívüli szomszédjukkal vagy olyan harmadik állammal való együttmüködésük fontosságát, amelyekhez hagyományosan szoros kulturális vagy gazdasági kapcsolatok füzik őket. Spanyolország például nagyobb támogatásért folyamodott az észak-afrikai államok számára, Németországnak alapvető érdeke a szoros kapcsolat fenntartása KözépEurópával, különösen Lengyelországgal. Németország saját stabilitását és majdani piacát biztosítja a lengyel gazdaság támogatásával és Lengyelországnak az EU gazdasági és biztonsági intézményeihez történö csatlakozásával. A belépés feltételei azonban szigorúak, és az EU keleti irányú bővitése nem csak a nyitott és demokratikus társadalmak fejlődésétől függ, hanem megfelelő csatlakozási politika 
kidolgozására a csatlakozni szándékozó országok részéröl eröfeszitéseket is igényel és olyan intézmények létrehozására, amelyek képesek a többoldalú együttmüködést és az államközi integrációt elősegíteni. Ezért a határmenti tervezési és a területfejlesztési együttműködés az EU és Lengyelország között fontos szerepet kap a csatlakozás elökészitésében. (Európai Bizottság 1994).

\section{TÁBLÁZAT}

A határmenti egyuittmüködés rendszere Európában

(Transboundary cross-border cooperation regimes in Europe)

\begin{tabular}{|c|c|c|c|}
\hline Normák & Hajtóerök & Intézmények & Eszközök \\
\hline $\begin{array}{l}\text { - nemzeti (illetve } \\
\text { felettes kormány- } \\
\text { zati) közvetítése } \\
\text { - szinergia: a } \\
\text { komplementitás } \\
\text { lehetőségeinek } \\
\text { kiaknázása } \\
\text { - partneri viszony: } \\
\text { a politikák össze- } \\
\text { hangolása több } \\
\text { szinten, addicio- } \\
\text { nalitás közős } \\
\text { finanszírozás } \\
\text { révén }\end{array}$ & $\begin{array}{l}\text { - kohézió } \\
\text { - a Közép-Európai } \\
\text { államok "pre- } \\
\text { integrációja" } \\
\text { - decentralizálás és } \\
\text { regionalizálás } \\
\text { - a térségi és helyi } \\
\text { kezdeményezések } \\
\text { támogatása } \\
\text { - versenyképes tér- } \\
\text { ségi politika ki- } \\
\text { dolgozása }\end{array}$ & $\begin{array}{l}\text { - kormányközi } \\
\text { bizottságok nemzeti } \\
\text { és térségi szinten } \\
\text { - informális parla- } \\
\text { menti munkacso- } \\
\text { portok } \\
\text { - Eurorégiók: helyi } \\
\text { központú intéz- } \\
\text { mények } \\
\text { - európai képviselet } \\
\text { spontán szervezö- } \\
\text { dések révén } \\
\text { (Európai Határmenti } \\
\text { Térségek } \\
\text { Szővetsége, AEBR) }\end{array}$ & $\begin{array}{l}\text { - strukturális politikai } \\
\text { ösztönzői (INTER- } \\
\text { REG) } \\
\text { - határmenti regionális } \\
\text { fejlesztési programok } \\
\text { - információáramolta- } \\
\text { tás és az együttmü- } \\
\text { kődéssel kapcsolatos } \\
\text { know-how átadása } \\
\text { (LACE) } \\
\text { - nyilvános fórumok és } \\
\text { politikai platformok } \\
\text { (CEMAT, Európa } \\
\text { Tanács, AEBR) }\end{array}$ \\
\hline
\end{tabular}

\section{A határmenti együttmüködés intézménye: és a német-lengyel együttmüködés környezete}

A német-lengyel határmenti térség helyzete számos olyan nehézséget megtestesít, amely a "Kelet" és a "Nyugat" közötti, határmenti együttmüködés új formáinak létrehozásával együtt jár. A határt a II. világháború után alakitották ki és térségét azóta is Európa egyik periférikus régiójaként tartják számon, ahol a gazdasági fejlödés lassú volt, és csupán szórványosak voltak a politikai légkör függvényében változó határmenti kapcsolatok. A kelet-lengyelországi elcsatolt területekröl (jelenleg Belarusz, Litvánia és Ukrajna részei) Pomerániába és Sziléziába, az egykori német tartományokba áttelepített lengyelek évtizedekig nem tudtak gyökeret verni a térségben, mert attól féltek, hogy visszacsatolják a frissen kapott földjeiket Németországhoz. Eltekintve a szerény léptékü ingázástól és bevásárlástól, a határmenti kapcsolatok fejlödésének nem voltak valós politikai lehetőségei. A közös határ mentén fennálló pszichológiai patthelyzet tehát ónmagában is nagyobb figyelmet érdemelt volna. A német-lengyel közeledés, a határral kapcsolatos viták rendezése és a felek békés egyưttélését elősegítö kétoldalú egyezmények csak 1989ben és 1990-ben végbement politikai változásoknak köszönhetően vált lehetségessé. A német újraegyesítés vetett véget az NDK elzárkózó határpolitikájának és a németeket, lengyeleket egyaránt sújtó utazási korlátozásoknak. 
A nemzetközi együttmüködések ösztönzése és a volt szocialista államok Európai Unióba történő bevonása érdekében azok a pre-integrációs együttmüködési formák kaptak nagyobb támogatást, amelyek egyértelmüen területfejlesztési igényeket szolgálnak és a gazdasági, politikai kohéziót erősítik. A német-lengyel, cseh-német, olasz-szlovén határ közelében élök és az EU többi keleti határrégiója viszonylag kevés tapasztalattal rendelkezik a határmenti egyưttmüködés terén, és hiányoznak az anyagi eszközök is az ambiciózus fejlesztési projektek finanszirozásához. Ezen régiók így szuikségszerủen az EU-hoz fordultak ösztönzésért, irányelvekért és pénzügyi segítségért. A "visszatérés Európába" mint a stabilizáció és gazdasági növekedés stratégiája (amelyet a PHARE-programokkal is támogattak 1989-töl) után a "pre-integrációs" politika került elötérbe, amely meghatározta a Lengyelországra, Magyarországra és más államokra vonatkozó tagsági követelményeket (különösen az agrárpolitika terén).

Lengyelország és más közép-európai országok esetében is szükségesnek tartották, hogy rövid időn belül létrehozzák a területi tervezési együttmüködés intézményeit, amelyek áthidalhatják a történelmi konfliktusok teremtette szakadékokat. Ennek egyik eszközét találták meg a többszintü képviselet stratégiájában ( $A E B R, 1992)$. Ez a német-holland és a Benelux határmenti térségekben kialakitott és kiérlelt módszer tartalmazza a teljes nemzeti közigazgatási kompetenciával felruházott hivatalos tanácsadó testületek felállítását is. (Scott 1993) A határmenti régiók tervezésével foglalkozó testületek felállítását - különbözö kormányzati szinteken - 1992-ben kezdték meg a német-lengyel határ mentén. Nemzeti szintü intézményeik a Területi Tervezés Kormányközi Bizottsága, a közös Környezetvédelmi Tanács, a Határvízi Bizottság és az Odera folyó Védelmének Nemzetközi Bizottsága. Tartományi, illetve regionális szinten különböző munkacsoportok és a Német-Lengyel Gazdaságfejlesztési Testület, helyi szinten pedig a Pomerániai Eurorégiók, a Pro-Europe Viadrina, a Spree-Neisse-Bober és a Neisse/Nysa szervezetei alakultak meg. (1. ábra) $\mathrm{Az}$ Eurorégiók intézményei a hasonló funkciót ellátó holland-német szervezetek mintájára álltak fel, a helyi és (a német oldalon) a megyei önkormányzatok közötti önkéntes együttmüködésével.

Az Eurorégiók fö célja, hogy elismerjék öket olyan nemzetközi szervezödésként, amely az adott régió gazdasági, környezetvédelmi, szociális és intézményi problémáival foglalkozik. Az ilyen tevékenységeknek Eurorégiók szintjén történö koncentrálásától azt remélik, hogy a német-lengyel együttmüködéssel olyan kritikus tömeget érhetnek el (gazdasági értelemben), amely erösíti határmenti térségek kohézióját, illetve felkelti magánbefektetők és intézmények érdeklödését.

Hosszú távú müködésük megszervezése és a területfejlesztési támogatásra vonatkozó új európai követelmények kielégitése céljából az Eurorégió-társulások - a holland-német szerveződésekhez hasonlóan - kidolgozták a Határmenti Fejlesztési Koncepciókat (TDC-ket), amelyek a határon átnyúló együttmüködés fö célkitüzéseit és a cselekvés lehetséges irányait határozzák meg. A TDC-k adják a konkrét projektek és javaslatok alapját, amelyek megvalósítása az EU, a nemzeti kormányok vagy más pénzügyi alapok támogatásával lehetséges. 
1. ABRA

Eurorégiók a nèmet-lengyel hatdr mentén

Euroregions on the German-Polish border

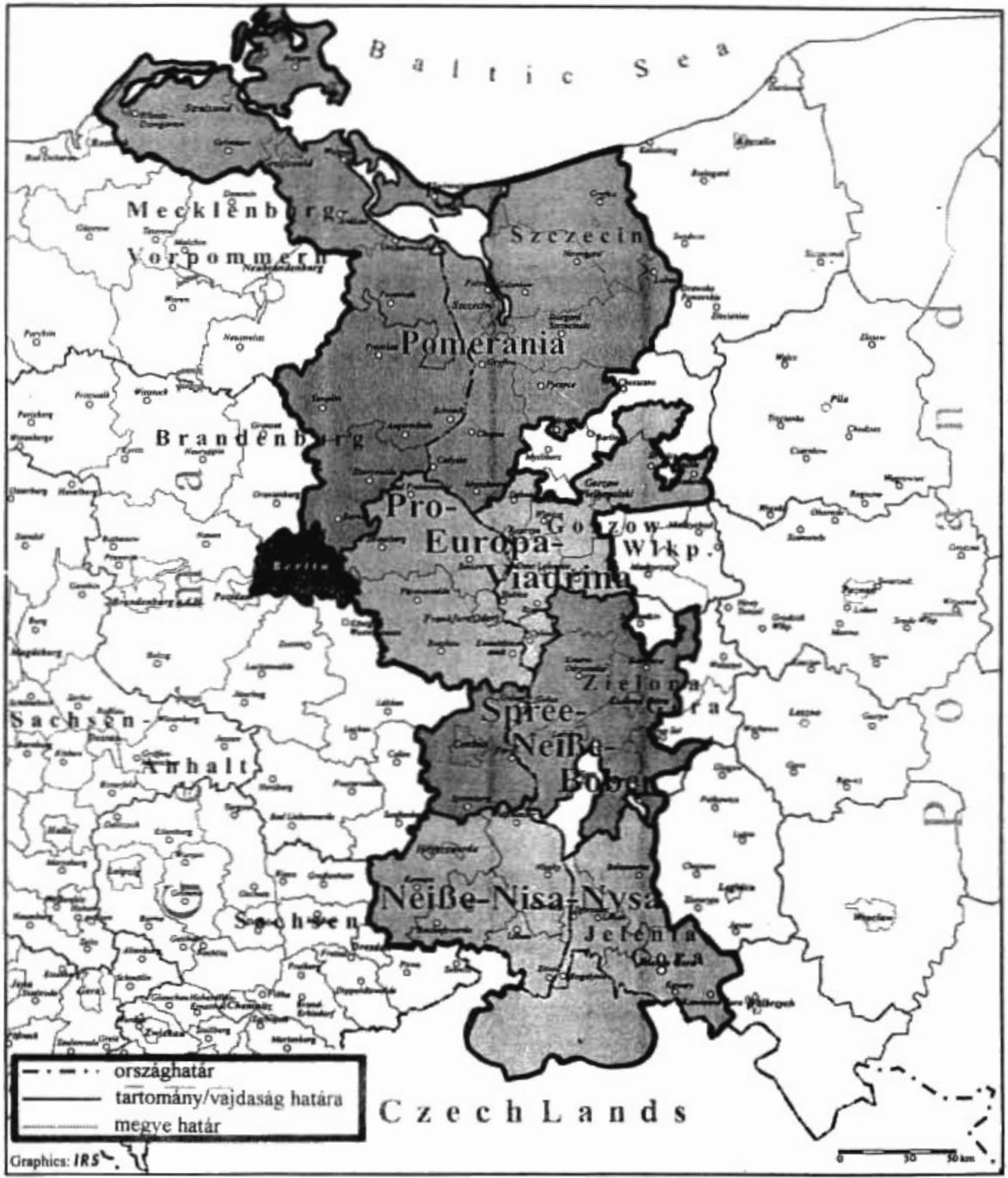


A német-lengyel határmenti együttmüködés különösen ígéretes területei lehetnek az elsősorban európai és nemzeti forrásokból finanszírozott új, lokális szinten megvalósuló programok. A PHARE-alapelvek 1994-es változásai óta Lengyelország PHARE-eszközeinek egy részét a határmenti térségek projektjeire fordítja és ezzel elméletileg lehetôvé válik közös programok megvalósitása a német régiókkal. Az utóbbiak számára az INTERREG program biztosítja pénzügyi feltételeket. Jelenleg az "INTERREG II/PHARE program - környezetvédelmi szervezetek és NGO-k ${ }^{11}$ által biztositott forrásokkal kiegészitve - nyújt pénzügyi támogatást számos helyi és térségi együttmüködési projekthez az EU külső határai mentén. A jelentősebb eredmények között tartják számon a közös szennyviztisztító létesítményeket, határmenti városok közös tervezési programjait, a közös természetvédelmi területek kialakítását, a felsőoktatási és ifjúsági csereprogramokat, illetve a közös adatbázisok kialakítását a területi tervezésben tevékenykedök és a régiókban müködỏ vállalkozások számára. A német-iengyel határmenti térségben az ehhez hasonló projektek a határmenti együttmüködésnek legpozitívabb elemei, mivel segítik a hatékony munkakapcsolat kialakitását a lengyel és német állami és magánszektor szereplöi között.

\section{Az együttmüködés külsö feltételei: a problémák kezelése}

A együttmüködés feltételeinek gyors kialakitása a területi tervezésben, illetve az Eurorégiók megalakulásában résztvevő politikusok, üzletemberek és más szereplök érdekeltsége és részvétele a folyamatban a néemt-lengyel határmenti kooperáció jővője, fejlödés szempontjából igen biztató. Az együttmüködés konkrét eredményei kevésbé egyértelműek, különősen akkor, ha összevetjuuk azokat a gazdasági kohézióra és a "pre-integrációra" vonatkozó célkitũzésekkel. Ennek egyik oka, hogy az európai területi politika és annak eszközrendszere nehezen igazitható a németlengyel határ térségére jellemző helyi és regionális sajátosságokhoz. Ezek többsége összefugg a poszt-szocialista átalakulás folyamatával, amely Lengyelország és Németország esetében számottevõ különbségeket mutat.

A német-lengyel együttmüködés helyi és regionális szintjén nemzetközi intézmények létrehozása ellenére a résztvevők politikai súlya, mérete eltérő. Németország szövetségi rendszerében a tartományok (és nem Bonn) feladata a területi tervezés és a területfejlesztési politika. Ezek intézményei jól müködnek a tartományokon belül, regionális szinten is. Lengyelországban azonban legfontosabb térségi szereplök (a vajdaságok) csak viszonylag gyenge koordinációs hatáskörrel rendelkeznek. Hiányoznak a területi tervezés regionális szintü intézményei, hatóságai, s ez politikai vákuumot teremtett a központi, illetve a helyi kormányzati szintek között. A helyi önkormányzatok szövetségei - például az Eurorégiók - nem helyettesithetik a regionális igazgatást. A két ország közötti különbségek az igazgatás mellett a gazdaságban, az életszínvonalban és a helyi kormányzatok rendelkezésére álló pénzügyi eröforrásokban is jelentösek.

A közigazgatási hatáskör diszkontinuitásai mellett ebben az összefüggésben figyelembe kell vennünk Kelet-Németország és Lengyelország helyi önkormányzatainak gyengeségeit is. A poszt-szocialista átalakulások viszonylagos politikai autonómiát és önkormányzatot biztositottak a helyi közösségeknek, s a folyamat a helyi kormányzatok tervezési hatáskörének jelentös bövülésével járt 
együtt. (Frzystacki 1992; Eilander, Gustaffson 1993). A helyi önkormányzatokra Kelet-Németországban és Lengyelországban 1989 óta új feladatok tömegét hárították. Számos helyhatóságra még ma is jellemző a központi, vagy más felsőbb közigazgatási szinttől való függés tudata, ami lassítja az önálló kezdeményezéseket és a más helyi közösségekkel alakuló "horizontális" kapcsolatokat (Osterland 1994; Keim, Grymer 1995). A poszt-szocialista területi politika hiányosságainak oka ugyanakkor a városok korlátozott képessége és szándéka az integrációs törekvésekben való részvételre, amelyben a gazdasági fejlődés és együttmüködés centrumainak szerepét kellene betölteniük. Ez sok esetben a helyi politika internacionalizálódását és a rövid távú gondolkodást eredményezett, ami szükségszerủen a stratégiai célok mellözésével, illetve mérsékelt támogatásával járt. (IRS 1995).

Ennek következményeként a német-lengyel határment régiókban a funkcionális kapcsolatrendszer alapvetően gyenge, és a belső munkakapcsolatok (nemzeti és nemzetközi szinten egyaránt) is elégtelenek a projekt-fejlesztés, a tervezés és más tevékenységek koordinálásához, amely a hatékony határmenti együttmüködés alapja. A vállalati szférában nagy léptékü átalakulások, átszervezések és összevonások történtek, s a folyamat szereplöinek sok esetben meg kellett küzdeniük versenyképességük megtartásáért. Ilyen körülmények között az egyoldalúság, a rövid távú gondolkodás és a puszta válságkezelés akadályozza az állami és a magánszektor közötti együttmüködés erősítését.

Ennek az eredménye, hogy a külsö támogatás és irányítás szerepe növekedett az említett térségekben. A helyi intézmények gyengék vagy tapasztalatlanok voltak az EU-programokban valórészvételhez. Ezt fokozta a koordinációhoz szükséges knowhow hiánya, a rendelkezésre álló források különbségei és a területi tervezés eltérő keretei. A határmenti településeknek és a (német) megyéknek kevés gyakorlati ismeretük volt a pénzügyi támogatások pályázati rendszeréröl, a projektek koordinálásáról és a Brüsszel által megkívánt könyvelési és egyéb adminisztratív normák alkalmazásáról.

Olyan kritika is érte az Eurorégiókat, hogy nem vállaltak elég aktív szerepet az INTERREG/PHARE-támogatásra benyújtott projektek stratégiai koordinálásában. A helyi önkormányzatok és az Eurorégiók résztvevői esetében egyaránt kívánatos lenne a stratégiai, hosszú távú szemlélet a térségi fejlesztéseknél, annak érdekében, hogy jelentősebb nagy projektre fordítsák erőforrásaikat és energiájukat a sok kisebb kezdeményezés helyett. Ezek a problémák terén a közös cselekvés lehetőségeinek teljes körü kihasználására ösztönzik a területi tervezés és fejlesztés szereplöit.

Az INTERREG és más kezdeményezések pozitiv vonásai ellenére a helyi önkormányzatok sok nehézséggel találták szembe magukat az EU és a nemzeti kormányok által támogatott projektek irányításakor. Az INTERRAG/PHARE programok a közös német-lengyel projektek kidolgozásának és megvalósításának keretei lehetnek. A projekt két partnerének költségvetését azonban szigorúan elkülönítetten kell kezelni, elkerülvén annak lehetöségét, hogy az EU pénzeszközei Lengyelországban, illetve a Lengyelországnak szánt PHARE-pénzek a német oldalon kerüljenek elköltésre. Az EU által alkalmazott területi elv még 
bonyolultabbá teszi a támogatások elnyerését, és eltántorítja a közösségeket attól, hogy a határ túloldalán keressenek partnert, illetve közös feladatokba vágjanak.

Egyértelmünek, hogy a határmenti területfejlesztési és tervezési programok kidolgozásának és koordinálásának feladata túlságosan összetett az Eurorégiók számára ahhoz, hogy egyedül lássák el azokat, jelentös segítség nélkül. Bizonyos stratégiai koherencia csak akkor érhető el, ha a projektek kiválasztása és kezdeményezése sokkal jobban illeszkedik a meglevő fejlesztési elvekhez. Ily módon a német-lengyel határ mindkét oldalát érintő programok végrehajtása során elkerülhetök a paternalista kormányzati beavatkozások olyan területeken, amelyek részei a projekt-orientált intézmény-épitésnek helyi és térségi szinten.

\section{Az együttmüködés feltételeinek javitása}

A német-lengyel határmenti együttmüködés szereplöinek sok új kihívással kell szembenéznie. Az eddigi együttmüködés jelentösen módosította az érintett régiók helyzetét közös programjaik feltételeit. Erre utalnak a politikai viták hangsúlyváltásai és a sajtó növekvő érdeklődése, amely jelzi a határmenti kapcsolatok fejlődését, s a folyamat szereplöinek tudatos szerepvállalását. Különösen figyelemre méltó a lengyel központi kormányzat felfogása az Eurorégiókról. A kezdeti fenntartások és szkeptikus hozzáállás eltünt, olyannyira, hogy Varsó önálló kormányhivatalon keresztül támogatja e programok megvalósítását, és nem vitatja a PHARE-pénzeszközök felhasználást sem a német-lengyel határ térségében. (Stryjakiewicz 1996). Az ebben a térségben folyó német-lengyel párbeszéd segitett lebontani a német-lengyel történelemben és a II. világháborúban gyökerezö lélektani akadályokat is. Az átalakulás első éveiben ugyan voltak ugyan feszültségek a német hegemóniától való félelem és a nemzeti szuverenitás elvesztése miatt, a németlengyel viszony azonban mostanra természetessé vált. ${ }^{12}$

Miközben a német-lengyel gazdasági együttmüködés ügye lassan haladt elöre, az egyes állampolgárok és a helyi önkormányzatok közötti kulturális kapcsolatok sikeresen alakultak, ami az itt élök képét saját, periférikus helyzetú régiójukról pozitív irányban változtatta meg. Többé nem probléma a határ két oldalán élő polgármestereknek, hogy rövid egyeztetés céljából találkozzanak, bürokratikus akadályok nélkül. A diákcsere-programok és a lakossága szomszédos ország közeli településeire szervezett látogatásai ma már mindennaposak. Az Európa Egyetem Frankfurtban (Frankfurt am Oder) 1992-ben ünnepelte az első tanév megnyitását. Ez a német-lengyel intézmény oktatási tevékenysége mellett sokféle diákszolgáltatást kínál (lakhatással egyưtt) mind Frankfurtban, mind a lengyel partnerintézményben, Slubice-ben, és fontos kulturális missziót teljesít a német-lengyel közeledésben.

A határmenti térségekben elindított, projekt-orientált kezdeményezések újabb pozitív példái annak, hogy a határmenti együttmüködés szereplöi hogyan tanulják kezelni a régión belüli problémákat. A néhány évvel ezelött még kivihetetlennek tartott közös müszaki projektek - mint például a Guben-Gubin melletti szennyvízkezelö telep - ma már befejezés elött állnak, a szakszerü irányitásnak köszönhetően. Az Eurorégiók és az állami szervezetek felismerték, hogy a stratégiai területfejlesztésnek az állami és magán szektor nagyobb mértékủ részvételén és együttmüködésén kell alapulnia. A projekt kidolgozásában az Eurorégió önkormányzatainak képviselői, a tervezöirodák, gazdaságfejlesztési szervezetek, a 
régióbeli cégek, a kutatóintézetek, egyetemek és az NGO-k részvételével alakult munkacsoportok vesznek részt.

A határmenti térségek eröteljesebben hangoztatják érdekeiket az együttmüködés feltételeinek javítása érdekében. Nyomást gyakorolnak Brüsszelre rugalmasabb és kezelhetöbb területfejlesztési programok előkészitéséért, és lobbiznak saját kormányuknál az állami infrastruktúra-beruházások gyorsítása és további támogatások megszerzéséért. Az eredmények szerények, mivel a Lengyelországban és a német tartományokban alkalmazott pénzügyi megszorítások behatárolják a periférikus fekvésü határmenti térségeknek nyújtott kormányzati támogatás mértékét. A közeljövö kétségkivuül megmutatja, hogy a német-lengyel határrégiók erősiteni tudják-e politikai súlyukat.

\section{Következtetések}

Az EU határmenti együttmüködési rendszerei nem egyik pillanatról a másikra változtatták meg az érintett térségek gazdasági és politikai szempontjából is marginális helyzetét. A napi politika szintjén a gazdasági átalakítás és intézmények modernizációjának különbségei lassították az együttmüködés feltételeinek kialakítását a határ két oldalán. A határokon átnyúló kapcsolatok támogatása mellett mindkét ország kormányzata (logikusan) olyan lépéseket tesz, melyekkel saját választóik számára igyekeznek kedvezőbb életfeltételeket biztosítani. A nyilvánvaló korlátok ellenére azonban a német-lengyel határ mentén formálódó kapcsolatok olyan fejlödést mutattak 1989 óta, amely példa nélküli a két nemzet történetében.

A német-lengyel határrégiók tapasztalatai azt jelzik, hogy a határmenti regionális együttmüködés hatékony formáinak kidolgozása érdekében állandó munkakapcsolatokat kell kialakítani az állami és a magánszektorban, amelyek alapja a kölcsönös bizalom, s amelyek nem elnyomják, hanem támogatják a meglevö törekvéseket. Valójában ez történik, bár még nem világos, hogy a periférikus határmenti térségekben ez a kapcsolatrendszer milyen mértékben bövíthetö. Felmerül a kérdés, hogy milyen következményekkel jár az ilyen típusú nemzetközi együttmúködés rendszerekre nézve az európai integráció további fejlödése és az új, határmenti regionalizmus erösödése Unión belül.

A "paradiplomácia" régióbeli és helyi szószólói nagyobb autonómiát és világos jogi keretek megalkotását sürgetik. Ugyanakkor a nemzeti kormányok, és általában a felsöbb igazgatási szintek érdeke felügyeleti szerepük fenntartása és a nemzeti határokon átnyúló kapcsolatok - mint például az együttes területi tervezés és a területfejlesztési együttmüködés - alapszabályainak megalkotása. Az európai integráció keretein belül ezek a szempontok nem szükségszerüen mondanak ellent egymásnak, és bizonyos mértékig még erősítették is a határmenti térségek pozícióit. Amint $O^{\prime}$ Dowd és szerzötársai megfogalmazták: "A határmenti térségek bizonyos jelzéseket adhatnak a nemzetállamok jövőjét illetöen. A nemzetállamok Európájában várható, hogy a határok fontos elemei maradnak a nemzeti szuverenitásnak, bár átjárhatóságuk gyorsan javul a jövőben. Az erősebb szálakkal összefüzött régiók Európájában viszont a határokon átnyúló együttmüködési rendszerek és intézményeik Brüsszelhez és a nemzeti kormányokhoz való közvetlen kapcsolódását kell erősíteni." (1995, 274. o.). 
Ma még csak találgatni lehet, hogy a határon átnyúló "puha" térségek létrehozása módositja-e a nemzetállam területi szuverenitáson alapuló igazgatási és ellenőrzési monopóliumát. Az EU-n belüli határrégiók - különösen a periférikus helyzetüek jövōjét alapvetōen pragmatikus szempontból kellene értelmezni. Hasznos-e gazdasági fejlödésük szempontjából, ha a nemzeti határon átnyúló kapcsolataik révén növelhetik politikai súlyukat? Kompenzálhatja-e ez a strukturális gyengeségeket? Vagy a jelenlegi - a versenyre és a helyi vállalkozói kezdeményezésekre épitkezō - EU-politika következtében megmarad e térségek erōs függése határmenti kapcsolataiktól és tágabb régiójuk fejlódésétől?

A német-lengyel példa esetében számos forgatókőnyv lehetséges, bár ezek megvalósulásának valószinűsége nem azonos. A komplementeritásra épülö németlengyel együttmüködésnek köszőnhetö általános gazdasági fellendülés esélye csekély az adott politikai és strukturális feltételek mellett. Még kevésbé várható azonban az egyoldalúsághoz és az elzárkózás politikájához való visszatérés, annak minden, a regionális fejlődésre gyakorolt negativ hatásával. Túl sok politikai tökét fektettek már a határon átnyúló együttmüködés fejlesztésébe. Jelenleg a periférikus területek nemzetközi szintü együttmüködéséröl beszélhetünk, olyan nemzetek feletti igazgatási szint formálódásáról, amely hatékonyan képes kezelni a helyi, vagy regionális szinten felmerülő problémákat, elősegíti e térségek gazdasági fejlödését és ellátja azok politikai képviseletét is.

A nehézségek ellenére, a német-lengyel Eurorégiók a kelet-nyugati együttmüködés igéretes példái. Lengyelország és Kelet-Németország gazdasági és politikai átalakulása során keletkező nehézségek ellenére ez a határmenti térség meglepöen stabil, ami nyilvánvaló bizonyitéka a két ország közötti kapcsolatok gyors normalizálódásának. A cseh-német Eurorégiók helyzete hét évvel az államszocializmus bukását kővetően is sokkal ingatagabb, amelyben a német és cseh nacionalista csoportok követelései és az általuk táplált hüvös politikai viszony fontos szerepet játszik.

Végezetül, a német-lengyel határon átnyúló együttmüködést fenyegetố valódi veszélyek nem kulturális vagy etnikai különbségekben rejlenek, hanem a válságkezelés és a támogatásokért folyó versengés kővetkeztében erōsödö rövidtávú, befelé forduló szemléletben. Ha ez bekövetkezik, a közös határ régiói és intézményei az európai integráció és a jószomszédság puszta jelképeivé válnak. Az aktív, határmenti regionális együttmükődés elöfeltétele a belső kohézió erősitése, a beruházások intenzívebb áramlása e térségekben, illetve a hajlandóság mindkét oldalon az egyưttmüködés új formáinak kialakitására, s az ezzel járó kockázat vállalására.

\section{Jegyzetek}

I A szerző az Institut für Regionalentwicklung und Strukturplannung (Erkner, Németország) munkatársa.

${ }^{2}$ Vo. M. Wulf-Mathies-nek, az Európai Bizottság tagjának az Európai Térségi Tervezés Stuttgarti Konferenciáján 1995. október 30-án tett kijelentésével.

${ }^{3}$ Panayotis Soldatos szavaival (1993): "A paradiplomácia kifejezés (...) a szub-nemzeti szereplôk (szôvetségi egységek, régiók, városi kózosségek, nagyvárosok) által kifejtett kozvetlen nemzetkơzi tevékenységre utal, amely a nemzetállam diplomáciaját támogatja, kiegésziti, helyesbiti, megkettōzi vagy kihivaás elé állitja; a "para" előtag a dịplomáciának a hagyományos nemzetállam-kereteken kivali 
alkalmazására utal" (Soldatos 1993). Az elmúlt negyven év során tơrtént kialakulásảnak fố oka a nemzetállamok által folytatott kalpolitika eszközeivel és prioritásaival való elégedetlenség volt. Amint Soldatos mondta (1993), ez diszfunkcióra utaló tūneti jelenség, és ugyanakkor a politika-alakitás racionalizálására tett kísérlet annak érdekében, hogy a külpolitikai diplomácia jobban figyeljen a szub-nemzeti igényekre és így hatékonyabb legyen.

${ }^{4}$ Lásd az EK 2081/93 számú, 1993. július 20-i irányelv 1. cikkelyét (Objectives)

${ }^{5}$ Az INTERREG célkitüzései: (1) a hatảrmenti tẻrségek elōkẻszitése az egységes piac bevezetésére, (2) a hatârmenti térségek gazdasági és társadalmi elszigeteltségének megszüntetése kōzvetien problémamegoldó intézkedések révén, (3) a határokon átnyúló együttmúkoodés és kapcsolatépités támogatása, és (4) az EU külsŏ határai mentén fekvō határmenti térségek felkészitése az egységes piacon rájuk váró „kapu-szerepére”. Az EU tett erōfeszitéseket a határokon átnyuuló egyuttmuâkodések Kôzẻp-Európában torténô fejlesztésére is. A PHARE és az INTERREG programok ennek jegyében mūkōdnek, valamint számos kisebb kezdeményezés, mint például a LACE és az OUVERTURE programok. Az INTERREG-kezdeményezés rơvid és kritikai ismertetését lásd. Scott (1996).

${ }^{6}$ Lásd az EK 2081/93. számú irányelvènek 4. cikkelyét.

${ }^{7} \mathrm{Az}$ Európa tanács, az EU, az AEBR ès számos más intézmény egyuttmükơdik, tơbbek kōzött a Határmenti Térségek Európai Konferenciájának elökészitésében, amely tobbbé-kevésbé rendszeresen megrendezésre kerül 1972 óta. E konferenciák az informális érintkezés lehetöségét jelentik a kormányzat különböző szintjeit képviselö, a határmenti térségek utgyeivel foglalkozó hatóságok számára, valamint platformokat maguknak a határmenti térségeknek a kőzös programjaik kidolgozására. Amint a konferenciák dokumentumai is mutatják, a teruleti tervezés és a fejlesztés politikai kérdésként jelennek meg.

${ }^{8}$ Lásd a 94/C 180/13 számú EK-Irányelv szövegét.

${ }^{9}$ A 94/C 180/13 számú EK-Irányelv (A5 bekezdés) egyértelmúen leszogezi, hogy az INTERREG nemzeti cselekvési programjait - amelyek a pénzeszkőzooknek az egyes kedvezményezet térségek számára tơrténõ elosztás alapjául szolgálnak - nemzeti, térségi és helyi kormányzatok kōzősen fejlesztik ki. Az Eurorégiók mint a helyi ónkormányzatok szōvetségei igy a helyi szintū strukturális programalkotási folyamatba tơrténổ bekapcsolódásának eszkōzeivé váltak.

${ }^{10}$ Lásd 1628/94 számú, 1994. július 4-ei EK-Irán

"NGO: Non-goverumental Organisation. A nemzeti kormányoktól fuggetlen szervezōdések.

${ }^{12}$ Lásd a német-lengyel viszony gyors vảltozảsainak elemzését például Adam Kremiski "Welchen Sinn hat Polen?" (Mit jelent Lengyelország?) cimũ irásảt a Die Zeit 1996. augusztus 16-i száma 3. oldalán

\section{Irodalom}

Akademie für Raumforschung und Landesplanung (1995) Zukunftsgaube Regionalplanung Anforderungen - Analysen - Empfehlungen. Vol. 200, Forschungs- und Sitzungsberichte der ARL

Association of European Border Regions (AEBR) (1992) Report on LACE Activities, Gronau.

Becker-Marx K. (1992) Modelle grenzuberschreitender Kooperation am Oberrhein. Versuch einer Kritik und einer Strategie. Verlag der ARL. Hannover.

Boyer R. (1996) The Convergence Hypothesis Revisited: Globalisation but Still the Century of Nations? In: Berger S., Dore R. (eds.) National Diversity and Global Capitalism. lthaca, Cornell University Press, 29-59.

Cappellin R. (1993) Interregional Co-operation and Internationalisation of Regional Economies in AlpsAdria. In: Horvath Gy. (ed.) Development Strategies in the Alps-Adriatic Region. Pécs, 17-45.

Church A., Reid P. (1996) Transfrontier Co-operation. Spatial Development Strategies and the Emergence of a New Scale of Regulation: the Anglo-French Border. Regional Studies 29. 3. 297-306.

Duchacek I. (1986) International Competence of Subnational Governments: Borderlands and Beyond. In: Martinez O.J. (ed.) Across Boundaries. Transborder Interaction in Comparative Perspective. El Paso, Texas Western Press, 11-28.

Duchacek L. (1987) Toward a Typology of New Subnational Actors in International Relations. Working paper 87-2, Institute of Governmental Studies, University of California, Berkeley.

Friedmann J., Morales R. (1984) Transborder Planning: A Case of Sophisticated Provocation? Working paper WCP 8, UCLA, Graduate School of Achitecture and Urban Planning.

Gabbe J. (1985) EUREGIO - regionale grenzuberschreitende Zusammenarbeit auf kommunaler Ebene. In: Institut fûr Landes- und Statenwicklungsforschung des Landes Nordrhein-Westfalen (ILS), Staatsgrenzenüberschreitende Zusammenarbeit des Landes NRW ILS. Dortmund, 90-98. 
Gabbe J. (1992) Institutionelle Aspekte der grenzuberschreitenden Zusammenarbeit. In: Akademie fur Raumforschung und Landesplanung (ed.) Grenzübergreifende Raumplanung: Erfahrungen und Perspektiven der Zusammenarbeit mit den Nachbarstaaten Deutchlands. Hannover ARL, 174-186.

Girot P. (1996) Border Regions, Integration and Transborder Conservation Initiatives in Central America. In: Scott J., Sweedler A., Ganster P. and Eberwein W.-D. (eds.) Border Regions in functional Transition: European and North-American Perspectives, Institute für egionalentwicklung und Strukturplanung. Berlin, 239-253.

Hansen N. (1992) Competition, Trust and Reciprocity in the Development of Innovative Regional Milieux. The Journal of the Regional Science Association International. 71. 2. 95-105.

Hooghe L., Marks G. (1996) Europe with Regions: Channels of Regional Representation in European Union. Publius: The Journal of Federalism 26. 1. 73-91.

Koch S. (1974) Toward a Europe of Regions: Transnational Political Activities in Alsace. Publius: The Journal of Federalism (nyár), 25-41.

Kratke S. (1995) Probleme und Perspektiven der deutch-polnischen Grenzregion. Analysen und Diskussionsbeitrage Nr. I., der verleichenden Stadt- und Regionalforschung. Europa Universitat Viadrina, Frankfurt am Oder.

Madiot Y. (1996) Aménagement du territoire. Paris, Armand Colin.

Malchus V. v. (1992) Deutch-polnische grenzubergreifende Zusammenarbeit. Erste Öberlegungen und Folgerungen. In: Akademie für Raumforschung und Landesplanung (ed.) Grenzöbergreifende Raumplanung - Erfahrungen und Perspektiven der Zusammenarbeit mit den Nachbarstaten Deutchlands. ARL, Hannover, 160-173.

Malchus V. v. (1992) Entwurf des Sachstandsberichts (LACE Issues Paper) über grenzübergreifende Zusammenarbeit zwischen Deutchland und Polen. 10.08.1992.

Millan B. (1994) Europe 2000: Territorial Aspects of European Integration. EUREG: European Journal of Regional Development, 1. 3-8.

O'Down L., Corrigan J, and Moore T. (1995) Borders, National Sovereignity and European Integration. International Journal of Urban and Regional Research. 19. 2. 272-285.

Pálné Kovács I. (1992) A teruleti politika irányitási ठsszefüggései, Tér és Társadalom 6. 1-2. 37-46.

Ratti R. (1988) Development Theory, Technological Change and Europe's Frontier Regions. In: Aydalot P., Keeble D. (eds.) High Technology Industry and Innovative Environments. London and New York, Routledge, 197-220.

Ratti R. (1993) How Can Existing Barriers and Border Effects Be Overcome? A Theoretical Approach. In: Cappellin R., Batey P.W.J. (eds.) Regional Networks, Border Regions and European Integration. London, Pion.

Scott J. (1993) The Institutialisation of Transboundary Co-operation in Europe: Recent Developments on the Dutch-German Border. Journal of Borderland Studies 1. (tavasz), 39-66.

Scott J. (1996) Dutch-German Euroregions: A Model for Transboundary Co-operation? In: Scon J., Sweedler A., Ganster P. and Eberwein W.-D. (eds.) Border Regions in Functional Transition: European and North-American Perspectives. Berlin, Institut für Regionalentwicklung und Strukturplanung, 83-106.

Scott J., Sweedler A., Ganster P. and Eberwein W.-D. (eds.) (1996) Border Regions in Functional Transition: European and North-American Perspectives. Berlin, Institut für Regionalentwicklung und Strukturplanung (IRS).

Software Union (1993) Entwicklungs- und Handlungskonzept für die Euroregion Pro Europa Viadrina, Berlin,

Soldatos P. (1993) Cascading Subnational Paradiplomacy in an Interdependent and Transnational World. In: Brown D., Fry E. (eds.) States and Provinces in the International Economy. Berkeley, USA, Institute of Governmental Studies Press, 45-64.

Stryjakiewicz T. (1996) Uwarunkowania Polsko-Niemieckiej Wsolpracy Przygranicznaj na tle Polityki Regionalnej. In: Chojniczki Z., Stryjakiewicz T. (eds.) Problemy, Wspolpracy Regionalncj w PolskoNiemieckim Obszarze Przygranicznym. Warsaw, Polska Akademia Nauk, 7-20.

Székely A. (1992) Establishing a Region for Ecological Co-operation in North-America. Natural Resources Journal 32. 563-622.

van der Veen A. (1993) Theory and Practise of Cross-Border Co-operation of Local Governments: The Case of the EUREGlO between Germany and the Netherlands. In: Cappellin R., Batey P.W.J. (eds.) Regional Networks, Border Regions and European Integration. London, Pion. 